\title{
TECHNOLOGICAL AND ENVIRONMENTAL ASPECTS OF ASSESSMENT OF A COMBINATION OF DIFFERENT MINING METHODS USED IN ESTONIAN OIL SHALE INDUSTRY
}

\author{
S. SABANOV*, K. SOKMAN \\ Department of Mining, Tallinn University of Technology \\ 5 Ehitajate Rd., 19086, Tallinn
}

\begin{abstract}
Oil shales used in Estonian power plants to generate electricity and in oil production are of different quality. Different excavation methods in use and accompanying development processes are accompanied by various emissions that can pollute water and air. However, generation of waste as well as impact on land use are of greater concern than emissions into the water and atmosphere.

Life Cycle Assessment (LCA) has proved to be one of the most attractive approaches to characterize sustainability of mining industry, as several environmental and economic indicators are used to assess its performance. The methodology enables to choose the best available environmentally friendly technology.

As shown by investigations, the mining processes exerts smaller effect on acidification, terrestrial eutrophication and ecotoxicity than production of auxiliary materials and transportation of oil shale to customers. Other impacts considered and discussed are ground surface subsidence, land use for deposited wastes and mine water pollution.

Assessment of the impact caused by a combination of different mining processes gives the opportunity to find a better way for planning new mines in accordance with environment protection measures in the area of the Estonia oil shale deposit.
\end{abstract}

\section{Introduction}

Environmental impacts associated with oil shale preparation and production are variable, as environmental impacts of mining methods used to extract oil shale using opencast or underground techniques are different [1]. The objective of this research was to consider all activities that usually take place around a mining site.

\footnotetext{
*Corresponding author sergei.sabanov@ttu.ee
} 
In this study, the Life Cycle Assessment (LCA) tool is used to analyze and assess the environmental impact of oil shale mining. The inputs and outputs of all the technological chains of mines and opencasts under investigation are determined. It means that also transportation and production of essential auxiliary materials (e.g. explosive, steel) are included in the life cycle system [2].

The company Eesti Põlevkivi Ltd. - company of oil shale production and distribution owns two operational mines (Estonia and Viru) and two operational opencasts (Narva and Aidu). The annual extraction of oil shale is 10-14 million tonnes, with $47 \%$ extracted by opencast methods and $53 \%$ by underground methods. The losses in underground mining are about 20-30\% (room-and-pillar method) and 5-10\% by opencast mining. Opencast mining is carried out at depths of 5-20 m and underground mining $-20-70 \mathrm{~m}$.

Nowadays new highly effective and environmentally friendly technologies are partially integrated into the mining processes. In the Estonia mine new technology is based on a blasting method applying emulsion explosives instead of packaged ones, change from $2.0 \mathrm{~m}$ to $4.0 \mathrm{~m}$ boreholes, and on a new large-hole undercutting method using modern machines. Loading and transportation of blasted mined rock is carried out by powerful LHD machines with diesel drive. The average productivity of such technology is $2000-4000 \mathrm{~m}^{3}$ of rock mass per day [3]. Using in opencasts continuous surface miner Wirtgen 2500SM for selective mining enhances the quality of oil shale. Through the cutting quality the mineral resource utilisation is more effective and environmental impact is less. The disturbing impact of drillingblasting operations in quarries and open pits next to densely populated areas causes vibration, dust and noise emissions which are arguments to stop operations where blasting is used. High-selective technology of surface miner is prospective owing to reduced dust and noise, as well as non-existent vibration [4].

The functional unit of the system under investigation is one tonne of oil shale. The functional unit is a reference unit, for which the inventory and impact assessment results will be presented, making it possible to compare the results of new and old mining technology. The aim of this study is to identify the differences between the environmental impacts caused by oil shale different extraction methods and production of auxiliary materials and transportation of oil shale to customers, and to give an overview of the environment protection measures of oil shale mining.

\section{The methodology}

The choice of mining methods in Estonian oil shale industry depend, to a great extent, on deposit depth. As deposit parameters determine the use of different equipment and extraction methods, the technologies can vary significantly [5]. The inventory data base represents a detail description of 
the mining system that comprises the description of excavation processes and analysis by classification and characterization methodology of LCIA [6]. These phases correspond to the methodology of LCIA recommended by the International Organization for Standardization [6]. The analysis involves data collection and description of unit processes for calculation procedures. The data collection includes all emissions associated with the oil shale excavation processes [7]. Descriptive information of unit processes is a necessary tool for evaluation operation option and environmental impact [8]. Description of unit processes presents a general overview of mining - what technology is applied and what equipment is used in the excavation processes.

At selection of impact categories and classification, appropriate impact categories were chosen and the collected inventory data (= environmental interventions such as emissions, land use and resource extractions) were classified into the selected impact categories according to their cause - effect relationships [14]. At characterisation, the chosen characterisation factors enable an aggregation of emissions within each impact category. The emission values are converted into impact category indicator values by multiplying the initial data by the corresponding characterisation factors [8] (Table 1).

Acidification $\left(\mathrm{SO}_{2}, \mathrm{NO}_{\mathrm{x}}\right.$ (expressed as $\left.\left.\mathrm{NO}_{2}\right), \mathrm{NH}_{3}\right)$ refers to the wet or dry deposition of acidic substances of anthropogenic origin on the earth's surface and is commonly called acid rain, but it includes also acid snow and acid fog. Acid rain is able to mobilize metals and other acid-soluble compounds from soil. Acids dissolve aluminum and other metals from soils in amounts becoming toxic to plants and aquatic organisms. Acid rain dissolves cement and minerals used at building [2].

Terrestrial eutrophication $\left(\mathrm{NO}_{\mathrm{x}}, \mathrm{NH}_{3}\right)$ can be defined as the state of increased nutrient availability in soil as a result of input of plant nutrients. The balance between nutrients available in the soil and natural vegetation has been disturbed in large areas in Europe mostly due to atmospheric input of nitrogen as a result of human activities. Excess inputs of nitrogen may lead to an undesirable shift in plant composition in natural or semi-natural ecosystems or loss of biodiversity. In addition, a high nitrogen load may affect groundwater making it unsuitable as a resource for drinking water [2].

Ecotoxicity (e.g. dioxins, PAH, PCB, metals, oil, cyanides and phenols in water) includes various chronic and acute effects on the natural organisms. In this work, the assessment of ecotoxicity is based on the EDIP 2003 methodology [13] in which the impact category is divided into two subcategories - chronic aquatic and terrestrial ecotoxicity. In aquatic ecotoxicity, airborne and waterborne emissions are taken into account, whereas emissions into the air (as fall-out) are taken into account in terrestrial ecotoxicity. In the determination of characterisation factors, the simple exposure model in which the environmental conditions of Northern and Eastern Europe are roughly taken into account predicts the concentrations of substances in the environment. In the method, the result is obtained by multiplying the emissions $(\mathrm{kg})$ by the corresponding characterisation factors $\left(\mathrm{m}^{3} / \mathrm{kg}\right)$ [14]. 
The selected impact categories correspond to the division recommended by the international LCA community [14] except for the group 'other impacts'. Other impacts consist of the local impacts caused by such factors as land use, solid wastes and water pumping from mines.

The characterisation factors change the values of interventions into the commensurable unit within the impact category so that the values of different interventions can be added together. The unit varies impact by impact depending on the chosen indicator for measuring the effects. For acidification and terrestrial eutrophication, the latest country-specific characterisation factors were used instead of site-generic characterisation factors [9]. This is due to the fact that the location of the emission source can cause different responses in the surrounding ecosystems in the context of these impact categories, depending, e.g., on local atmospheric conditions and the sensitivity of the ecosystems [10]. In the context of these three impact categories, the emissions of life cycle stages were calculated using characterisation factors specific to Estonia. It is assumed that all important interventions occur in Estonia. Thus, for acidification and terrestrial eutrophication Estonia-specific characterisation factors were used (Table 1).

Table 1. Characterisation factors and reference value for acidification and terrestrial eutrophication [11]

\begin{tabular}{|c|c|c|c|}
\hline Impact category & Emission & Unit & Factors for Estonia \\
\hline \multirow{2}{*}{ Acidification } & $\mathrm{SO}_{2}$ & & 0.369 \\
& $\mathrm{NO}_{2}$ & \multirow{4}{*}{ eq/kg } & 0.194 \\
& $\mathrm{NH}_{3}$ & 0.405 \\
\multirow{2}{*}{ Terrestrial eutrophication } & $\mathrm{NO}_{2}$ & & 1.483 \\
& $\mathrm{NH}_{3}$ & & 4.418 \\
\hline
\end{tabular}

Different acidifying emissions were aggregated by characterisation factors, which are derived from the results of European air quality and transport model [11] and critical loads determined over Europe [12]. The critical load means that harmful effects will occur if the deposition of acidifying emissions exceeds a certain limit.

\section{Results and discussion}

Data offered by Eesti Põlevkivi were the basis to study emissions from mines into water and air according to impact categories like acidification, terrestrial eutrophication and ecotoxicity. Annual outlet of mining water and air has served as the measure of emission. For an opencast, gaseous emission into the air was calculated considering diesel combustion of working machines (the processes of stripping, cutting, drilling, loading, transportation, recultivation). The supply unit of blasting operation - the production of ammonium 
nitrate from ammonia and nitric acid $\mathrm{NH}_{4} \mathrm{NO}_{3}$ - was used to calculate the emission from the explosion process. Some machines work only on electricity and do not apply diesel combustion, therefore emissions attributed to power generation were calculated.

Emissions from mining, transportation of oil shale to customers and auxiliary material production accompanied with production of oil shale are presented in Table 2.

Table 2. Emissions per one tonne of extracted oil shale (Eesti Põlevkivi 2005)

\begin{tabular}{|l|c|c|c|}
\hline \multicolumn{1}{|c|}{ Activity } & $\mathrm{SO}_{2}$ & $\mathrm{NOx}$ & $\mathrm{NH}_{3}$ \\
\hline Viru mine & $3.00 \mathrm{E}-02$ & $8.00 \mathrm{E}-04$ & \\
Estonia mine & $1.00 \mathrm{E}-02$ & $4.00 \mathrm{E}-04$ & \\
Aidu opencast & $4.00 \mathrm{E}-02$ & $4.00 \mathrm{E}-02$ & \\
Narva opencast & $6.00 \mathrm{E}-02$ & $3.00 \mathrm{E}-02$ & \\
Mining total & $1.00 \mathrm{E}-01$ & $6.00 \mathrm{E}-02$ & \\
Auxiliary material & $4.00 \mathrm{E}-02$ & $6.00 \mathrm{E}-02$ & $1.00 \mathrm{E}-02$ \\
Transportation & $1.00 \mathrm{E}-02$ & $2.00 \mathrm{E}-01$ & \\
\hline
\end{tabular}

\section{Acidification}

At assessment, the effects of emissions causing acidification were expressed with the help of an indicator called 'accumulated exceedance'. It describes the effects as acidification equivalency (eq) where eq corresponds to $1 \mathrm{~mol}$ proton $\left(\mathrm{H}^{+}\right)$released. [12].

In the Viru mine, acidification is three times higher than that in the Estonia mine. Opencasts emit more $\mathrm{NO}_{\mathrm{x}}$ resulting in greater acidification. (Fig. 1a).

a)

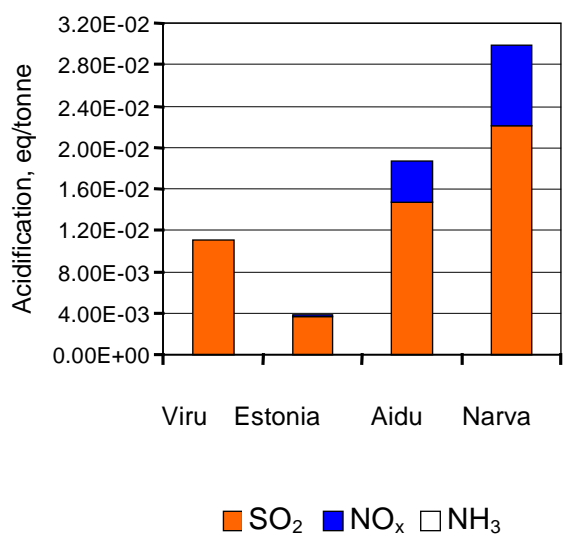

b)

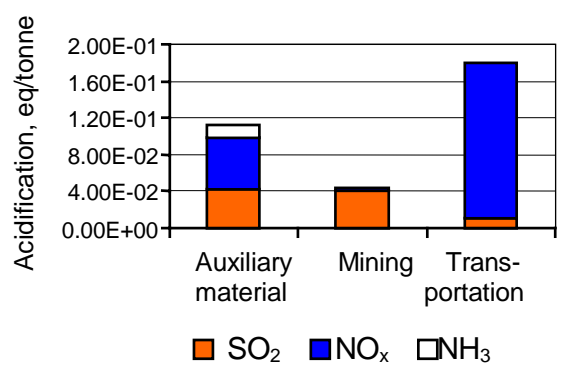

Fig. 1. Contribution of different emissions to the acidification process. $\left(\mathrm{NH}_{3}\right.$ is "out of scale" because of its low amount). 
The result showed that mining causes less acidifying emissions than the production of auxiliary materials (including production of diesel oil, explosives, steel etc.) and transportation of oil shale to customers. Also, as for acidification, the main contributor in the mining process is $\mathrm{SO}_{2}$, while at transportation the level of $\mathrm{SO}_{2}$ is not so high as that of $\mathrm{NO}_{\mathrm{x}}$ (Fig. 1b).

\section{Terrestrial eutrophication}

Terrestrial eutrophication means a state of increased nutrient availability in soil as a result of input of plant nutrients. The characterisation method is based on the same approach as used in the case of acidification [14]. In the context of terrestrial eutrophication, an indicator describes the accumulated exceedance of critical loads of eutrophication. It measures the effects as eutrophication equivalency (eq) that corresponds to $1 \mathrm{~mol}$ nitrogen.

The Narva opencast is the leader of $\mathrm{NO}_{\mathrm{x}}$ production in comparison with the mines Aidu and Estonia. However, the role of the Viru mine in terrestrial eutrophication is insignificant (Fig. 2a).

Transportation of oil shale to customers causes more impact on terrestrial eutrophication than production of auxiliary materials and mining (Fig. 2b).

New machinery and modern technology in the Estonia mine should guarantee greater extraction of oil shale than in the Viru mine using old machinery. On the other hand, old machinery works only on electricity and does not emit from diesel combustion, therefore its emissions are calculated considering power generation. In opencasts, surface miner Wirtgen 2500SM used for selective mining allows to exclude the drilling-blasting process. Necessary data for evaluation of emissions can be calculated from the specification of the corresponding equipment.

a)

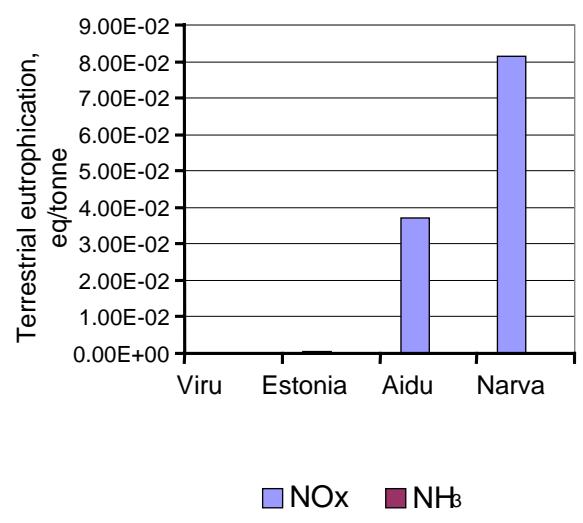

b)

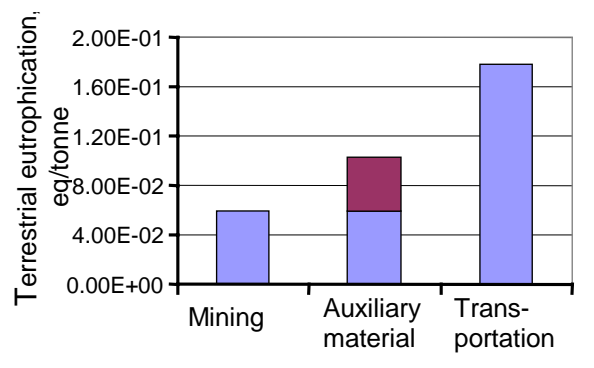

Fig. 2. Contribution of different emissions to the terrestrial eutrophication processes. $\left(\mathrm{NH}_{3}\right.$ is "out of scale" because of its low amount). 


\section{Ecotoxicity}

The measure of ecotoxicity is obtained by multiplying the emissions $(\mathrm{kg})$ by the corresponding characterization factors $\left(\mathrm{m}^{3} / \mathrm{kg}\right)$.

In comparison with auxiliary material production (Fig. 3), the role of excavation processes is less.

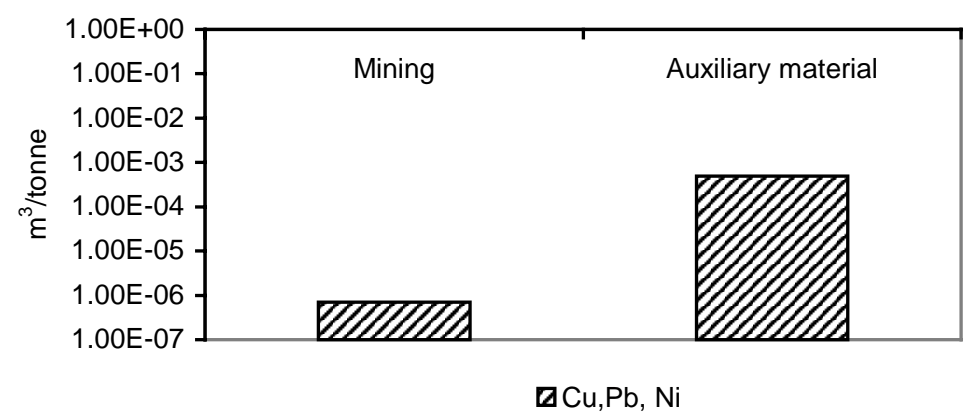

Fig. 3. Contribution of oil shale mining and production of auxiliary materials to chronic terrestrial ecotoxicity.

\section{Ground surface subsidence and land use}

The processes in overburden rocks and pillars have caused unfavorable environmental side-effects accompanied by significant subsidence of the ground surface. Ground surface subsidence can cause soil erosion and flooding, swamp formation, agricultural damage, deforestation, changes in landscape, decrease in groundwater level and make the formation unstable. Nowadays underground oil shale excavation is made by room-and-pillar method with blasting. The commercial oil shale bed and immediate roof consist of oil shale and limestone seams. The main roof consists of carbonate rocks of various thicknesses. The characteristics of various oil shale and limestone seams are quite different. The strength of the rocks increases in the southward direction. For this reason, stability of pillars is difficult to prognose. Ground surface subsidence results in pillar collapse. Depth of a subsidence depends on the thickness of the extracted seam. The first spontaneous collapse of pillars and surface subsidence in an Estonian oil shale mine took place in 1964 [15].

Up to the present, over 70 spontaneous collapses of chamber blocks in Estonia, Viru, Ahtme and Tammiku mines have been recorded [16]. Figure 4 shows that most of collapses occurred during 30 months of the exploitation, the number decreasing to the point of 60 months. Collapses of chamber blocks after the period of 60 months occurred in locations of complicated geological conditions and below the area of rock dump formation under loading. 
a)

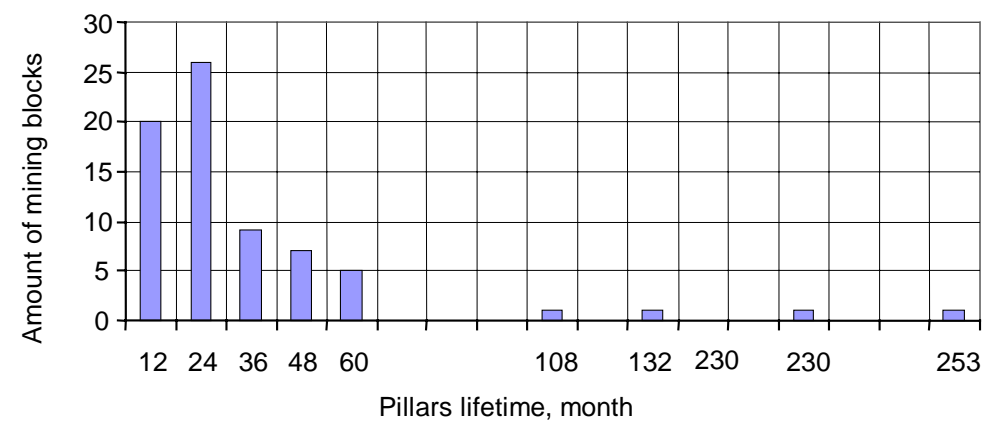

b)

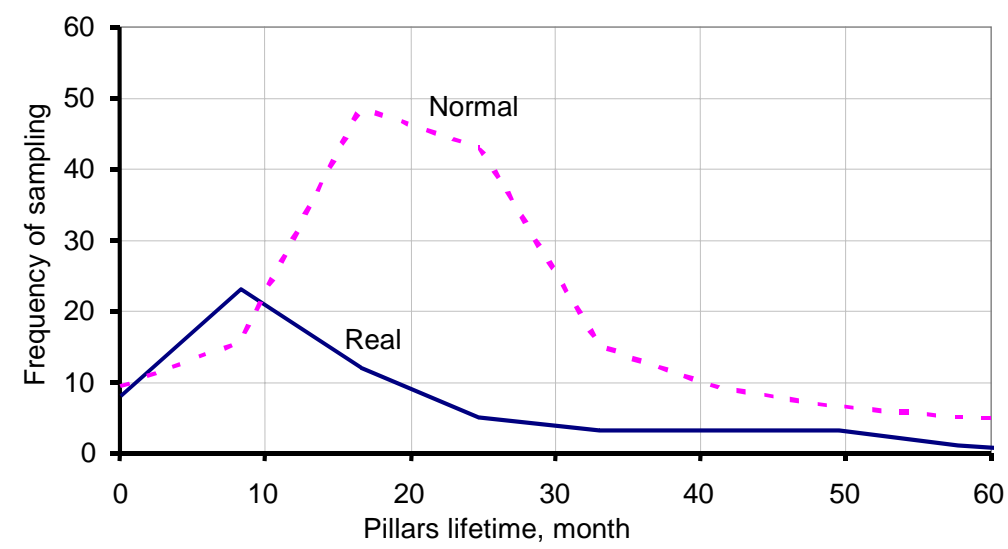

Fig. 4. a) The amount of collapsed chamber blocks during the time period under investigation. b) Logarithmic normal distribution of pillars' lifetime.

Statistical data and analysis of pillars' lifetime [16] enabled to express pillars collapsed during this period in the logarithmic normal distribution scale. Logarithmic normal distribution, as a rule, well approximates such random variables $X$ which are formed as a result of multiplication of a big number of independent or poorly dependent non-negative random variables; the dispersion of each is small in comparison with the dispersion of their sum. Summation of data enables to assume that chamber block collapses occurring during 60 months were caused by diminishing cross-sectional area of pillars and increasing chamber volume (Fig. 4b).

The total volume of waste from oil shale mining is 180 million tonnes, and it covers 188 ha from mines and 150 ha from opencasts forming a coneshaped dump. The volumes of waste used as landfills were 70 million tonnes in the Estonia mine and 35 million tonnes in the Viru mine. From the area as 
large as $220 \mathrm{~km}^{2}$, oil shale has been mined by underground method. $61 \%$ of the total amount of oil shale has been extracted from underground mines. A half tonne of waste is generated per tonne of extracted oil shale in the process of oil shale enrichment. Wastes destroy agricultural land cover and ecosystems. In the case of surface mining, a very successful recultivation method allows to restore ecosystem and landscape.

The mining causes many local environmental impacts affecting land use and ground surface subsidence which cannot be assessed by the life cycle impact assessment methodology.

\section{Mine water pollution}

Annual water outlet of the mining enterprises of Eesti Põlevkivi Ltd. amounts to 200-240 million $\mathrm{m}^{3}$ (Fig. 5) [17]. On this reason, the depth of the sinkhole reaches $70 \mathrm{~m}$, with impact radius 5-10 km. Disturbances in the natural regime of groundwater bring about changes in its chemical composition. The pumped-out water does not meet the requirements to waters discharged into the environment. In the course of mining, water becomes enriched with saline compounds, containing, for instance, up to $500 \mathrm{mg} / \mathrm{l}$ of sulphates instead of natural $20 \mathrm{mg} / \mathrm{l}$. The content of minerals has increased to $1 \mathrm{~g} / \mathrm{l}$ (natural $0.3-0.4 \mathrm{~g} / \mathrm{l}$ ). Several breakdowns of mines have caused pollution with phenols, up to hundreds times exceeding their permissible limit $(0.001 \mathrm{mg} / \mathrm{l})$ [18].

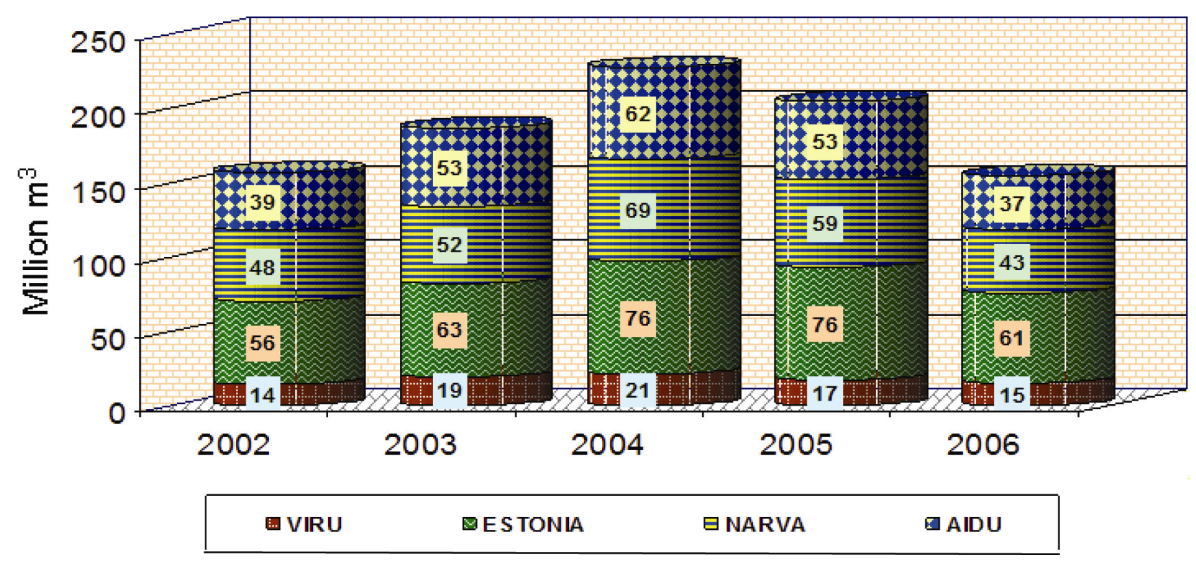

Fig. 5. Mining water outflow. 


\section{Conclusions}

As shown by investigation, mining processes cause smaller impacts on acidification, terrestrial eutrophication and ecotoxicity than production of auxiliary materials and transportation of oil shale to customers.

Statistical analysis of pillars' lifetime shows that pillars collapsed during the period under investigation express logarithmic normal distribution. Summation of data enables to assume that chamber block collapses occurred during 60 months because of diminished cross-sectional area of pillars and increased chamber volume. Correct choice of dimensions of pillars and chamber will guarantee stability of the ground surface. To present subsidence of ground surface and restriction of land use, it is recommended to use the backfilling method, which allows to restore the ecosystem and landscape.

Mining waters exert minor impact on the composition of natural waters: the amount of heavy metal compounds in mining waters is lower than their natural level in North-East Estonia.

The method of technological and environmental assessment of the impact of a combination of different mining processes gives an opportunity to find a better way for planning new mines in accordance with environment protection measures for conditions of the Estonia oil shale deposit.

\section{Acknowledgements}

Estonian Science Foundation (Grant No. 6558, 2006-2009) supported the research. This study is a part of Estonian Science Foundation Grant No. 7499 "Conditions of sustainable mining" and a part of the project No. SF0140093s08 of Estonian Ministry of Education and Research.

\section{REFERENCES}

1. Jaber, J. O., Probert, S. D. Environmental-impact assessment for the proposed oil-shale integrated tri-generation plant // Applied Energy. 1999. Vol. 62, No. 3. P. 169-209.

2. Talve, S., Põld, E., Koskela, S., Sokka, L., Hiltunen, M.-R., Seppälä, J. Task 1 of OSELCA project: Life Cycle Assessment of Oil Shale Electricity. www.energia.ee/OSELCA 2005.

3. Nikitin, O., Sabanov, S. Immediate roof stability analysis for new room-andpillar mining technology in "Estonia"mine // Proceedings of the $5^{\text {th }}$ international scientific and practical conference. Latvia, 2005. P. 262-269.

4. Nikitin, O., Väli, E., Sabanov, S., Pastarus, J.-R. The surface miner sustainable technology introduction for oil-shale mining in Estonia// Environment Technology Resources. $6^{\text {th }}$ International Scientific and Practical Conference / G. Noviks, V. Morozov, R. Tepfers, W. Leal, T. Chrzan (eds.). Rezekne, Latvia: RA Izdevnieciba, 2007. P. 55-61. 
5. Durucan, S., Korre, A., Munoz-Melendez, G. Mining life cycle modelling: a cradle-to-gate approach to environmental management in the minerals industry // J. Clean. Prod. 2006. Vol. 14, No. 12-13. P. 1057-1070.

6. ISO 14042. Environmental management - Life cycle assessment - Life cycle impact assessment. International Organization for Standardization, Geneva, 2000.

7. ISO 14040. Environmental management - Life cycle assessment - Principles and framework. International Organization for Standardization, Geneva, 1997.

8. ISO 14041. Environmental management - Life cycle assessment - Goal and scope definition and inventory analysis. International Organization for Standardization, Geneva, 1998.

9. Seppälä, J., Posch, M., Johansson, M., Hettelingh, J.-P. Country-dependent characterisation factors for acidification and terrestrial eutrophication based on accumulated exceedance as an impact category indicator // Int. J. LCA. 2006. 11 LCA (6). P. 403-416.

10. Amann, M., Cofala, J., Heyes, C., Klimont, Z., Schööpp, W. The RAINS model: A tool for assessing regional emission control strategies in Europe // Pollution Atmosphérique. 1999, 20. P. 41-46.

11. EMEP. Transboundary acidifying air pollution in Europe. EMEP/MSC-W Report 1/98, Norwegian Meteorological Institute, Oslo, 1998.

12. Hettelingh, J.-P., Posch, M., Slootweg, J. (eds.) Critical loads and dynamic modelling results. CCE Progress Report, 2004. Coordination Center for Effects, RIVM Report 259101014, Bilthoven, Netherlands, 2004: Vol. 134.

13. Hauschild, M., Potting, J.. Human toxicity and ecotoxicity // Background for spatial differentiation in life cycle assessment - the EDIP 2003 methodology / J. Potting, M. Hauschild (eds.). Institute of Product Development, Copenhagen, 2004.

14. Seppälä, J., Koskela, S., Sokka, L., Talve, S., Põld, E., Hiltunen, M.-L. Comparison of the environmental performances of oil shale and coal electricity: life cycle impact assessment and interpretation. A report of the EU-Life project, OSELCA, 2005. Available at www.energia.ee/OSELCA.

15. Pastarus, J.-R., Sabanov, S. A method for monitoring working mining block stability in Estonian oil shale mines // Proc. Estonian Acad. Sci. Eng. 2005. Vol. 11, No. 1. P. 59-68.

16. Reinsalu, E., Toomik, A., Valgma, I. Mined-out Land.. - TUT. Department of Mining, 2002. 97 pp. [in Estonian].

17. Homepage Eesti Põlevkivi. www.ep.ee (19.08.2006)

18. Ida-Viru District. Human Impact on Environment / J.-M. Punning (ed.). Institute of Ecology and Marine Research, Estonian Academy of Sciences. Tallinn, 1991.

Received September 20, 2007 